\title{
Edebî ve Kolektif Bellekte Mehmet Âkif İhtifalleri*
}

\author{
İbrahim ÖZTÜRKÇÜ**
}

Öz

Biyolojik yaşam defterlerini ölümle kapatan şair ve yazarlar, geride bıraktıkları eserlerle, toplumsal bellekte varlıklarını devam ettirirler. Sürekli hatırlanmak, unutulmamak, vefaya mazhar olmak, hayırla/rahmetle anılmak, her yıl törenlerle yeniden hafızalarda yaşamak, her yazarın gönlünde taşıdığı gizli emellerdendir. Şairlerin bu arzusunu gerçekleştirmek için adlarının sokaklara, meydanlara, kamu kurumlarına verildiği, hatıralarına heykeller dikildiği, saygılarına her yıl yarışmalar düzenlendiği, dernekler ve vakıflar kurulduğu görülür. Bedenini toprağa, anılarını toplum hafızasına emanet eden ölülerin/yazarların hatıralarını yaşanır kılan şey, kalemlerinin gücü, özgün üslupları, edebiyatta açtıkları çığırın boyutu, toplumun hislerine ve düşüncelerine orijinal nitelikteki tercümanlıklarıdır. Vefatı sonrası edebî hafızada her zaman tazeliğini koruyan ve Yeni Türk edebiyatında ismi etrafında her yıl olumlu/olumsuz tartışmaların eksik olmadığı şairlerden biri de Mehmet Âkif’tir. Birinci ölüm yıldönümünden başlayarak günümüze gelinceye kadar gerek resmi kurumlar, gerek sivil toplum kuruluşlarının düzenlediği kesintisiz anma törenleri sebebiyle Mehmet Âkif, Türk edebiyatında bir istisna teşkil etmektedir. İhtifaller, şairin hayatına, sanatına ve eserlerine dair yeni bakış açılarının ortaya çıkmasına vesile olduğu gibi edebî polemiklerle kültürel hafızanın canlanmasına da hizmet etmektedir. Bu makalede şairin adını yaşatmak adına düzenlenen ihtifallerin/anma törenlerinin şahsiyetine ve eserlerine katkısı irdelenmiş, kolektif bellekteki izi sürülmüştür.

Anahtar Kelimeler: Mehmet Âkif, İhtifal, Toplumsal Bellek, Halkevleri, Yıldönümleri.

\footnotetext{
* Bu makale Doç. Dr. Turgay Anar danışmanlığında yapılan Yeni Türk Edebiyatında İhtifal ve Jübileler başlıklı doktora tezimden üretilmiş bir bölümdür.

** Doktora Öğrencisi, İstanbul Medeniyet Üniversitesi, Lisansüstü Eğitim Enstitüsü, Türk Dili ve Edebiyatı ABD, İstanbul, Türkiye.

Elmek: ibrahimozturkcu@gmail.com

https://orcid.org/0000-0001-9545-9786.
} 


\title{
Mehmet Âkif's Commemorations in Literature and Collective Memory
}

\begin{abstract}
Poets and writers, who close their biological life notebooks with death, continue their existence in the social memory with the works they left behind. They are remembered constantly, and they will not be forgotten. Moreover, they will be honoured, remembered with goodness/mercy, and live in memories. Yearly ceremonies are among the personal goals that every writercarries in his heart.

In order to realize this desire of poets, it is seen that their names are given to streets, squares and public institutions. Statues are constructed in their memories. Besides, competitions are held every year in their esteem, associations and foundations are established.

The memory of the dead authors, who entrusted their bodies to the soil, lays in the pen power. Furthermore, the author's original styles, the extent of the breakthroughs they presented in the literature, and their original interpretations of society's feelings keep them alive. Mehmet Âkif is one of the poets who always preserves his freshness in the literary memory after his death. There is no shortage of positive/ negative discussions around his name in New Turkish literature. From the first anniversary of his death to the present day, almost ever yyear, commemoration ceremonies are organized by official institutions and non-governmental organizations. Commemoration ceremonies revived the cultural memory with literature polemics, being instrumental in the emergence of new perspectives on life, art, and poets' work.

Hence, Mehmet Âkif constitutes an exception in Turkish literature. This study will examine the contribution of the celebrations/commemoration ceremonies organized to keep the poet's name alive, and his traces in the collective memory will be traced.
\end{abstract}

Keywords: Mehmet Âkif, Revolution, Social Memory, Community Centers, Anniversaries. 


\section{Giriş}

Yaratılıştan itibaren varlığın karşısına bir alınyazısı olarak konulan ölüm, evrensel bir gerçek olarak hayatın merkezinde her zaman yer almaktadır. Behçet Necatigil'in Garnitür şiirinde vurguladığg gibi insan hayatında “yaşamak ilk bölüm, ölüm son bölüm”dür (Necatigil 1975: 4)1

Her canlının hayatının nihayete ermesi zaruri, aşikâr ve kaçınılmaz bir son olarak dinî metinlerde ve Kur'an-1 Kerim'de "Her insan/can ölümü tadacaktır. Sonunda Bize döneceksiniz.” şeklinde kesin bir hükümle vurgulanmıştır. ${ }^{2}$ Hayata gelişi, kutlu ve uğurlu bir hadise kabul edip özel merasimler tertip ederek kutlayan insanoğlu, ölümü de üzüntüyle karşılayıp birtakım törenlerle acısını hafifletmeyi bir ritüel haline getirmiştir. Bütün törenler arkasında dinî, örfi, sosyolojik, psikolojik, antropolojik, politik ve kültürel birtakım sebepleri de barındırmaktadır.

Eric Hobsbawm'ın “icat edilmiş gelenekler” sınıfına dâhil ettiği modern haliyle merasimler, ancak 19. yüzyılda ortaya çıkan 20. yüzyılda yaygınlık kazanan ritüellerdir. "İcat edilmiş gelenek” terimi, Eric Hobsbawm’a göre, gerçekten icat veya inşa edilmiş, formel (şeklî) düzlemde kurumsallaşmış gelenekler ile birlikte, "kolayca izi sürülemeyecek bir şekilde kısa ve belirlenebilir bir zaman diliminde -belki de birkaç yılda- ortaya çıkmış olan ve büyük bir hızla yerleşmiş gelenekleri kapsamaktadır. Bu tabirle "gizli veya açık kabul görmüş kurallarca yönlendirilen ve bir ritüel ya da sembolik bir özellik sergileyen, geç-

1 "Ölümler söyletir

Sağlık, sığlık susarız,

Gömülü gönlümüzde

Ölümdür.

Konumuza dönelim

Yaşamak ilk bölüm

O kolay anlaşıldı

Ölüm son bölümdür!"

2 Âli İmrân Suresi (3), âyet 185; Ankebût Suresi (29), âyet 57; Kur'ân-ı Kerîm ve Türkçe Anlamı (Meâl), (1985), Ankara: Diyanet İşıleri Başkanlığı Yayınları, s. 73, 402. 
mişle doğal bir süreklilik anıştırır şekilde tekrarlara dayanarak belli değerler ve davranış normlarını aşılamaya çalışan pratikler kümesi" kast edilmiştir. (Hobsbawm-Terence: 2006, 2) İcat edilmiş geleneklerin izini sürmede, y1ldönümleri, anma törenleri ve her türlü merasim kültürel belleğin laboratuvarındaki en ideal denek ürünleridir. Michael Schudson'ın ifadesiyle "yaşayan hatıra olasıllğının giderek sönükleştiği yerde, geriye yalnızca kültürel olarak kurumsallaştırılmış anılar" toplamı olan törenler kalmaktadır (Schudson 2007: 183).

Saptanmış kurallarca yönlendirilen, zaman içerisinde resmi bir kimliğe bürünen ve simgesel nitelik taşıyan törenler, belirli bir kalıba dökülerek yineleme eğilimi taşıdıklarından kolay kolay kendiliğinden değişimlere uğrayıp çeşitlenmezler. Paul Connerton, anma törenleri gibi formel (biçime bağlanmış) eylemlerin uygulayım yoluyla korunduklarına dikkat çekmektedir. Bu törenlerin uygulayımsal olmaları ve biçimselleştirilmiş bulunmaları nedeniyle, onları uygulamayı alışkanlık edinmiş kimselerce, kolay kolay eleştirel dikkatli incelemelere ve değerlendirmelere konu edilebilecek nitelikte değillerdir. Connerton'a göre hem anma törenleri hem de enformel bedensel pratikler, tüm söylem pratiklerinde görülen, birikimli sorgulamalara karşı içlerinde bir ölçüde güvence taşımaktadır (Connerton 1999: 158).

Edebiyatçılar için gerek hayatlarında düzenlen jübileler, gerekse vefatları sonrası tertip edilen ihtifal/anma törenlerinin yaslandığı temel teorik ilke, "kültürel bellek, edebî hafiza, toplumsal/kolektif bellek" kavramlarıyla doğrudan ilgilidir. Çünkü birliğinin ve kimliğinin temellerini oluşturan paylaşılmış duygu ve düşünceleri düzenli aralıklarla pekiştirmek ve onaylamak ihtiyacı duymayan bir topluluk yoktur. Bu ahlâki tekrar-yapılanma, ancak bireylerin birbirleriyle bütünleştiği, birbirlerinden destek aldığ 1 , kendisi gibi olanların varlığının verdiği güvenle ortak değerlere bağlılığını mevcudiyetiyle ilan ettiği doğum, ölüm, evlenme, bayram gibi dinî veya kültürel amaçlı ortak sosyal alanlarda ortaya çıkar (Karateke 2017: 236-237).

Merasimlerin ve anma toplantılarının temelini teşkil eden kolektif bellek, Emile Durkheim ve onun izinden giden Halbwachs'ın geliştirdiği tezle- 
rin bir parçasıdır. Maurice Halbwachs' in ${ }^{3} 1950$ yılında neşrettiği La Mémoire collective (Kolektif Hafiza), neşrinden yıllar sonra büyük bir yankı uyandırmıştır. O zamana kadar bireysel bilincin odağı sayılan hafıza, doğrudan bir grup ya da toplum adı verilen kolektif bir varlığa bağlanmıştır. Önceki çalışmalarında "hafızanın toplumsal çerçeveleri” kavramını oluşturan Halbwachs, daha sonra anılarını hatırlamakta olan kişisel hafıza çalışmasının kolektif hafızaya başvurduğunu ortaya koymuştur. Halbwachs'ın, bu tezi "Anımsamak için başkalarına gereksinim vardır.", "Asla tek başımıza anımsayamayız." şeklinde özetlenebilir (Ricoeur 2012: 139). Zira anı tipolojimizde hafızayla ilgili iki büyük olgu olan hatırlama ve tanıma olgularına doğru giden yolda başkalarının hafızasıyla karşılaşırız. Bu yolda rastlanılan ilk anılar, paylaşılan anılar, ortak anılardır (reminiscing-yâd etme). Bu anılar sayesinde "aslında asla yalnız olmadığımız”, doğuştan getirdiğimiz birliktelik/dayanışma ruhu, pekiştirilir, böylece bir varsayım olarak "tekbencilik" devre dışı bırakılmış olur (Ricoeur 2012: 140).

İnsanların birbirleriyle etkileşimlerinin yoğunluğu oranında iyi işleyen bir toplumsal bellek ortaya çıkar, böylece ortak amaçlara sahip olan kişilerin toplumun çoğunluğunu oluşturmaya başlar. Bireyler arasındaki ortak noktalar çoğalırsa o toplumlarda çeşitli simgelerin anlamları üzerinde ileri derecede bir birlik oluşur (Karateke 2017: 236). Burada simgelerden kasit, Antropolog Paul Connerton'un işaret ettiği, kolektif hafızanın oluşmasını sağlayan performans/bedensel pratikler ve tekrarlardır. Ritüelleri icra etmek için bir araya gelen gruplar, tekrarlar sayesinde kolektif alışkanlıklar edinirler. Yalnız bu süreç zarfında insanlar, belli jestleri, belli hareketleri her yıl veya periyodik aralık-

\footnotetext{
3 Fransız Sosyolog Maurice Halbwachs 1920'li yıllarda özellikle üç kitabında işlediği "toplumsal bellek" kavramını ortaya atmıştır: Belleğin Sosyal Çerçevesi-1925, Kutsal Toprakta Incil'in Efsanevi Topografyast. Ortak Anılar Üzerine Bir Inceleme-1942, Toplumsal Bellek-1950. Halbwachs IV. Henry Lisesi'nde okurken, bellek konusunu felsefesinin merkezine koyan Bergson'un öğrencisi oldu (H. Bergson 1896), ardından Durkheim ile çalıştı. Durkheim'in toplumsal bilinç kavramı daha sonra Bergson'un sübjektivizmini aşmasına yardımcı oldu ve belleği sosyal bir olgu olarak yorumlamaya dayanan çalışmalarının temellerini oluşturdu. Halbwachs önce Strasburg, ardından Sorbonne Üniversitesi'nde sosyoloji dersleri verdi. 1944 yılında Collége de France'a tayin edildiği sıralarda Almanlar tarafından Buchenwald toplama kampına gönderildi ve burada 16.3.1945'de öldü. Bkz. Jann Assman, Kültürel Bellek: Eski Yüksek Kültürlerde Yazı, Hatırlama ve Politik Kimlik (2015), çev. Ayşe Tekin, İstanbul: Ayrıntı Yayınları, s. 43.
} 
larla tekrar etmeleri gerekir. Connerton, bedensel pratiği şöyle açıklamaktadır:

"Geçmişin versiyonlarını, geçmişi kendimize, onu temsil eden sözcüklerle ve imgelerle yeniden sunarak koruruz. Anma törenleri bu pratiğimizin önde gelen örneğini oluşturur. Söz konusu törenler, geçmişi, geçmişin olaylarının temsil edici bir resmini çizerek kafamızda tutmaya yarar. Bunlar, geçmişin yeniden canlandırılmasıdır; sıradan durumlarda, anımsama, sahnenin ya da durumun bir taklidinin, temsili giysiler içinde geri dönüşleridir. Bu tür yeniden canlandırmaların retorik inandırıcılığı, gördügümüz gibi, önceden belirlenmiş bedensel davranışlara dayanır...” (Connerton 1999: 113).

\section{İhtifal Nedir?}

Arapça haft kökünden türeyen ihtifal kelimesi "toplamak, önem vermek" anlamında olup, "Büyük bir kalabalıkla yapılan anma töreni”ne karşılık gelmektedir. Kelimeye "Büyük bir alay ile hürmet ve ta "zîm" anlamını veren Şemsettin Sâmi, devamında "Başlıca cenaze alayları hakkında müsta 'meldir." diyerek şu örneği vermiştir: "Na'şı ihtifâlât-1 lâzime ile kaldırıldı." (Şemseddin Sâmi 1317/1899: 75-76).

II. Meşrutiyet sonrası İttihatçıların Alemdar Mustafa Paşa'yı hatırlaması üzerine ihtifale dair tarihi bir okuma yapan Kemalettin Kuzucu, bugün anma töreni diye ifade edilen ihtifal geleneğini, İttihat ve Terakki popülizminin, Meşrutiyet' $i$ ve bunun öngördüğü yönetim sistemini kitlelere benimsetmek için etkin biçimde kullandığ1 araçlardan biri olarak görmektedir. Kuzucu'ya göre tarihi ihtifallerle altı yüz yıla yayılan parlak zaferlerin şanlı kahramanlarının yeniden hatırlatılmasıyla halkın bozulan maneviyatının yükseltileceği hesap edilmiştir. İttihatçılar, Türk milliyetçisi olarak takdim edilmeye çalışılsa da aslında İslam birliğini de savunmakta, fakat imparatorluğun devamı için "Meşrutiyetçi Osmanlıcılık" düşüncesini hepsinden ziyade önemsemekte idiler. Kuzucu, ihtifaller üzerinden İttihatçıların popülizme kayan amaçlarını şöyle açıklamaktadır: 


\begin{abstract}
"Osmanlı milletini oluşturan farklı etnik gruplar arasındaki ayrışmayı durdurup siyasal birliği yeniden tesis etmek için milleti kökleriyle buluşturacak dinî, millî ve örfî değerleri canlı tutmaya gayret etmişlerdir. İmparatorluğun kurucu kadrolarının kabirlerinin tamir edilip buralara resmî ziyaretler düzenlenmesi, İstanbul'un fetih yıldönümünün kutlanması, fatih padişahlar, büyük kumandanlar, sanatkârlar ve şairler için mevlit okutulması gibi etkinliklerin hepsi bu düşüncenin ürünüdür. Nadir de olsa bir olay ve kişi için anıt dikilmesi de bu devirde görülür." (Kuzucu 2018: 12-13).
\end{abstract}

Kuzucu'nun dikkat çektiği "milli serpuş, millet vapuru, Turgut Reis ve Barbaros zırhlısı, Reşid Paşa ve Midhat Paşa gemileri, Alp Arslan gazetesi, 23 Temmuz Bayramı (10 Temmuz Hürriyet Bayramı), İstiklâl-i Osmanî Bayramı" gibi teşebbüsler, İttihatçıların kitle siyasetine ve toplumsal belleğin yeniden inşasına dair girişimlerinin bir tezahürüydü (Kuzucu, 2018: 61-103). İttihatçılar, kolektif belleği ve tarihi, -Connerton'un da altını çizdiği üzereiçerisinde bedensel pratikler barındıran törenler, siyasal sembol değeri taşıyan (padişah, şehzade, vezir, paşa, kahramanlar) ve mitleşmiş şahsiyetler üzerinden yeniden kurmak istiyorlard1.

Maarif Nezareti Dördüncü Şube Müdürü İhtifalci Mehmet Ziya Bey'in (1865-27 Mart 1930) girişimleriyle II. Meşrutiyet sonrası yaygınlık gösteren ihtifal geleneği, İhtifal-i Millî Heyeti adıyla özel bir teşebbüs sayesinde koordine edilmekteydi. Mehmet Ziya Bey dışında heyetin diğer üyeleri şunlardı: İstanbul Sultanîsi Müdürü Süreyya Bey, Maarif Nezareti müdürlerinden Cemal ve Hulusi Beyler, Nuri, Şemseddin, Sadri, Said ve Veysi Beyler, Darülmuallimîn Müdür Muavini Feridun Bey ve mütekait kaymakam ve Muallim Nasuhi Bey (Çoruk 2016: 84).

Meşrutiyet'in ilanı sonrası Ertuğrul Gazi, Sultan Osman, Fatih Sultan Mehmet, Nevşehirli Damat İbrahim Paşa, Sokullu Mehmet Paşa, Şeyh Galip, Barbaros Hayreddin Paşa, Mimar Sinan gibi Türk büyükleri için anma faaliyetleri ve İstiklâl-i Osmanî, 10 Temmuz Îd-i Millîsi, 23 Nisan Milli Bayramı gibi milli günler ve bayramlar için şenlikler düzenlemekle tanınan Mehmet 
Ziya Bey, İhtifal-i Millî Heyeti Reisi olarak II. Meşrutiyet’ten Cumhuriyet'e hatırı sayılır bir ivme kazanan ihtifal geleneğinin, milli (İstanbul'un fethi vb.) ve dinî (Mevlid) törenlerin hem teorisyeni hem de uygulayıcısıdır (Eyice 2003: 174-175) "Maziyi tebcîl, en büyük an'ane-i milliyedir!" sloganıyla memlekette ilk defa büyüklerimizin hatıratını yâd etmek, milli ve dinî bayramlarda ulusal birlik ve bilincin tesisine hizmet etmek üzere ihtifaller, toplantılar düzenlediğinden ve bu sahada tek başına ulusal bir bellek inşasına giriştiğinden isminin önüne "İhtifalci" sıfatı konulmuştur (Ergun 1947: 22).

İhtifalci Ziya Bey'in izinden giden ve ölümüne kadar Nef'’̂, Nedim gibi Divan edebiyatı şairleri ile Recâizâde Mahmut Ekrem, Tevfik Fikret, Abdülhak Hâmit, Süleyman Nazif, Ahmet Rasim, Ziya Gökalp gibi tanınmış edebiyatç1lara, Zekai Dede gibi musiki üstatlarına ve Mimar Sinan gibi sanatkârlara ihtifal düzenleyen, birçoğu hakkında ithaf şiirleri yazan, ayrıca milli şahsiyet ve günlere dair manzumeler neşreden Florinalı Nâzım (Özgünay, 1883-1939) da, anma geleneğinin önemli simalarından biri olarak zikredilmelidir (Ayvazoğlu 2007: 2-3).

\section{Sessiz Yaşadım Dedikçe Çığlığa Dönüșen Ses}

27 Aralık 1936 Pazar günü akşam saat 19.30'da vefat eden ${ }^{4}$ Mehmet Âkif, "rahmetle anılmayı", ebediyete ulaşmanın ön şartı sayarak Safahât’ta

"Toprakta gezen gölgeme toprak çekilince,

Günler şu heyûlâyı da er, geç silecektir.

Rahmetle anılmak, sonsuzluk budur amma,

Sessiz yaşadım, kim beni, nerden bilecektir?”

diyerek tahassürde bulunmuş ve "gölge" imgesiyle fani vücudunun kısa süre içerisinde unutulup gideceğini ifade etmiştir (Ersoy 2001: 499). Bu dize üzerine Hakkı Süha Gezgin, öldükten bu kadar sene sonra arkasında "kaynayan damar, çarpan yürek, yükselen heyecan bırakan adam"1n ancak gövdesiyle fani olduğunu ve dünyanın her tarafında bu türlü bahtiyarlara "büyük adam" 
denildiğini yazmıştır. Gezgin'e göre Âkif, kendi kokusundan habersiz bir çiçek gibi tevazu ve vakar ile "Sessiz yaşadım, kim beni nerden bilecektir?" dedikçe kalplerde daha çok derinleşmiş, fikirlerde daha ziyade yükselmiştir (Gezgin 1940: 3).

Karakterinin en kuvvetli tarafi "dürüstlük", şairliğinin en cazip tarafı "samimiyet" olan Mehmet Âkif, ölümünden sonra da kendisinden daha çok bahsedilen nadir kalem sahiplerinden biridir. İbrahim Alâettin Gövsa, Âkif’i hayatında "muhafazakârlığına meclûb" olan yaşlıların, öldükten sonra da "Âkif' in selis nazmında çarpan kalbini, bilhassa Çanakkale ve İstiklal mücadelelerinden duyduğu ve duyurduğu heyecanı seven" gençlerin fazlasıyla beğendiğini söylemektedir. Şairin vefatı sonrası cenazesindeki tezahürler, kabrinin yapılması uğrundaki teşebbüsler ve günümüze kadar uzanan ölüm yıldönümündeki ihtifaller, konferanslar ve ziyaretler de -Gövsa'ya göre- onun şahsiyet ve ahlâkını sahiplenen münevver memleket gençliğinin eseridir (Gövsa 1939: 3).

“Kalabalıkların sempatisine her zaman şüphe ile bakılması" gerektiğini düşünen Orhan Okay, şüpheli nice şöhretin, birer moda gibi, kısa zamanda sönüp gitmesine ve Âkif'in, ölümünün üzerinden yarım asır geçmesine ve resmi ilgiden uzun zaman mahrum olmasına rağmen, "ehemmiyetini korumasını ve milletin gönlündeki yerini muhafaza etmesini” anlamlı bulmaktadır. Milletimizin, Mehmet Âkif'e gösterdiği bu ilgisinin çeşitli sebeplerini Orhan Okay şöyle sıralamaktadır:

“O, 1908 sonrası siyaset ve fikir arenası ortasında müstesna ve tutarlı tek şahsiyettir.

$\mathrm{Bu}$ arenada, alışılmış bir tabirle, ona sadece İslam şairi demek, fazla bir şey ifade etmez. Bir İslam idealinin şairi olan Âkif, Müslüman'1, gelecek bir dünyanın şartları içinde düşünüyordu. Âkif' in şairliği münakaşa konusu olmuştur. Manzum hikâye yazarı, vaiz gibi sıfatlar, ona kolaylıkla yakıştırılmak istenmiştir. Mamafih, halk tarafından sevilmesinde bu sıfatının önemli olduğu düşünülebilir. Bununla beraber o, demin bahsettiğim fikir ve siyaset arenasındaki şairlerin arasında, sanatkâr vasfı taşıyan tek insandır (Okay 1989: 3-4).” 
Mehmet Âkif anmaları, defnedildiği gün (28 Aralık 1936) kabri başında bir grup üniversite öğrencisinin aldığı kararla başlamıştır. Şairin Türk bayrağına sarılı tabutu otomobile konmak yerine eller üzerinde taşınmak suretiyle Beyazıt'tan Edirnekapı'ya kadar götürülmüsstür. Resmi törenden mahrum bir şekilde defin merasimi yapılan şairin maskı (yüzünün kalıbı), ailesi ve yakın dostlarının onayıyla, Heykeltıraş Ratip Âşir (Acıdoğu, ölm. 1957) tarafindan büstü yapılmak üzere alınmıştır. Bu yönüyle Âkif, Tevfik Fikret’ten sonra maskı alınan ikinci şair olarak edebiyat tarihimizde yerini almıştır. Devletin ilgi göstermediği Mehmet Âkif'in mezarının yapılması işini Edebiyat Fakültesi Talebe Cemiyeti üstlendiği gibi törene katılan talebeler, her sene bir “Mehmed Âkif Günü” yapmak ve her y1l Aralık ayının 28'inci gününde, şairin mezarı başında birleşmek için karar vermişlerdir (Kara-İbanoğlu 2011: 93-94, 105-106).

Vefatından hemen sonraki Âkif anmalarında üniversite camiası adına Edebiyat Fakültesi Metinler Şerhi mütehassısı Dr. Ali Nihat Tarlan, hem hatip hem de öğrencileri yönlendiren bir organizatör olarak karşımıza çıkmaktadır. Âkif'in ölümünün birinci yıldönümünden itibaren Üniversite konferans salonunda gençlerin düzenlediği ihtifallerin hatibi Âkif'in yakın dostları ile birlikte Ali Nihat Tarlan'dır. Bugün de olduğu gibi anma törenlerine sayg1 duruşu ve ardından okunan şairin ölümsüz eseri İstiklal Marşı ile başlanmaktaydı. Bu da şairin edebî hafızadaki milli simgesinin İstiklal Marşı olduğunun genel kabul görmüş bir göstergesidir. Ölümünün ikinci yıldönümündeki ihtifal konferans metninde Tarlan, şairin hayatını ve şahsiyetini, edebî hüviyetini ortaya koyarak soğukkanlı tahlillerde bulunmuştur. Bu yönüyle o, gençlerin Âkif'i doğru anlamasında öncü bir şahsiyettir. Tarlan, kitabın sonuna düştüğü notla şairin her yıl çeşitli vesilelerle hatırlanmasına imkân tanıyacak ihtifallerin kararlıl1kla sürdürüleceğine dair kanaatini de şöyle ortaya koymuştur: "Hayır, büyük şair, müsterih uyu. Ne sen unutulabilecek bir insansın. Ne biz seni unutabilecek bir nesiliz." (Tarlan 1939: 15). 
Sühulet Basımevi'nden yayınlanan ihtifal kitabında Ali Nihat Tarlan, eserin sonuna şöyle bir not düşmüştür: "Hâsılatı Âkif'in kabri için sarf edilecektir." Nottan Tarlan'ın gençlerin şaire kabir yapma teşebbüslerine yardımcı olduğu anlaşılmaktadır. Tarlan, gençlere hitap ettiği ihtifallerde dinin ve milli hislerin istismarına karşı Âkif'i örnek göstermiş, edebiyat tarihindeki yerini ve konumunu eserlerinden örnek vermek suretiyle tahlil etmiştir. Ahlâkın halka din gibi metafizik bir zarf içinde sunulmasını Âkif'in içtihatlarından biri olarak zikreden Tarlan, bu içtihadın hata olsa bile, çok titiz bir ahlâkîlik endişesinden mülhem bir içtihat olduğuna dikkat çekmiştir. Tarlan'a göre "Âkif, dini edebiyatımızın bilâ-kaydu'ş-şart en muvaffakiyetli şairidir." (Tarlan 1939: 5-15).

Şairin vefatından bir yıl sonra 1937 yılında Edebiyat, Hukuk ve Tıp Fakültesi öğrencilerinin tahassüslerini ve Âkif'in şahsiyetine ve edebî kimliğine dair değerlendirmelerini içeren derleme de, ilk ihtifal/anma metinlerinden biridir. Bu kitapçıkta yazısı bulunanlar arasında Atsız, M. Turhan Tan, Dr. İhsan Unaner, A. Karahan, Abdurrahman Konuk (Hukuk Fakültesi), Namık (Hukuk Fakültesi), N. Salih, Mustafa Kemal Ergenekon (Edebiyat Fakültesi), Ahmed Ruhi (Hukuk Fakültesi), Necmi Gözen (Hukuk Fakültesi), Muzaffer Kemal (Tıp Fakültesi) gibi isimler yer almaktadır. ${ }^{5}$ Kitapta milliyetçi vurgu belirgin bir şekilde hissedilmektedir ki bu isimlerden bazıları (Atsız), daha sonra aşırı Türkçü eğilimin önemli temsilcisi haline gelecektir. Bu öğrenci grubu, bir edebiyat otoritesi sayılan Ali Nihat Tarlan'ın himayesi altında organize olarak Âkif' in kabrinin yapılması için birkaç broşür neşretmiştir. Bu kitapçıklarda şairin bir toprak yığınından ibaret ve bakımsız kabrinin o zamanki durumu da açık bir şekilde görülmektedir. Broşürde genç talebeler bu ölüm karşısında duygularını kâğıda dökmekle kalmamış, Âkif'e bir kabri çok gören zihniyete karşı kendi çaplarında bir reaksiyon geliştirmişlerdir. Broşürün sonunda “Edirnekapısı'nın harap mezarlığında yağmurlu, karlı bir günde” geçen 
"Mezarsız Faciasının Son Perdesi" adlı bir oyun vardır. Mezarcı ile Edebiyat Fakültesi'nden Kemal Ergenekon arasında geçen diyalogla Âkif'in mezarsız kabrinin içler acısı hali trajedi unsurlarıyla okuyucuya verilmektedir. ${ }^{6}$ Veteriner Fakültesi Talebe Cemiyeti de Âkif’i ölümünün 2. ve 3. yıldönümünde "unutmadıklarını ve unutmayacaklarını" göstermek amacıyla birer broşür neşreden aktif cemiyetlerdendir. ${ }^{7}$

1938-39 yılında Mehmet Âkif'in yakın dostlarından Eşref Edip'in iki cilt halinde kaleme aldığı Mehmet Âkif: Hayatı, Eserleri ve 70 Muharririn Yazıları adlı eserin neşri, her y1l kabrinde yapılan ihtifallere rağmen, şairi bir kez daha tartışmaların odağı haline getirmiştir. Sabiha Zekeriya Sertel'in Fikret'i bayraklaştıran yazıları ve Tevfik Fikret-Mehmet Âkif'in Kavgası eseri iki şairin lehinde ve aleyhinde polemik gruplarının oluşmasına neden olmuştur. İhtifallerin yerini ithamlar almış ve mesele Âkif'in hiç sevmediği bir vadiye, "şahsiyât"a dökülmüştür. ${ }^{8}$

1940 yılında Maarif Vekâleti "büyük adamlar için her sene değil, 5 senede bir ihtifal merasimi yapılmasına" karar verdiğinden bu tarihten itibaren resmi Âkif ihtifalleri bir müddet sekteye uğramıştır. Vefatından sonra hemen her yıl, birçok vesile ile hatırlanan Mehmet Âkif’in ölüm yıldönümleri mezar ziyareti şeklinde Üniversite profesörlerinin ve gençliğin katılımıyla sürdürülmüştür. ${ }^{9}$ Resmiyetin bıraktığı boşluğu bu tarihlerde, çoğu zaman kendiliğinden organize olan, sivil teşebbüsler doldurmuştur. Prof. Ali Nihat Tarlan ve Tıp Fakültesi'nden Fethi Tevet(oğlu), mezar ziyaretlerinde nutuklarıyla öne çıkan isimlerdir. ${ }^{10}$ Kabri başında gençler, Âkif'in şiirlerinden birkaçını oku-

6 Broșürde yazısı bulunan diğer talebeler șunlardır: Abdurrahman Konuk (Hukuk Fakültesi), M. Atsızayoldaș, A.(hmed) R.(uhi) (Hukuk Fakültesi), M. Onbaşıoğlu Ahmed Ruhi (Tıp Fakültesi), M. S. (Hukuk Fakültesi), O. Altyörük (Tıp Fakültesi), S. Doğu (Tıp Fakültesi), Ş. Edgüer (Tıp Fakültesi), Ergenekon (Edebiyat Fakültesi). Bkz. Mehmet Âkif'in Kabri İçin (t.y.) İstanbul: y.y., $16 \mathrm{~s}$.

7 Vefat y1ldönümlerinde șaire dair talebelerin duygu ve düșüncelerini içeren bu broșürler, Âkif' in "hakiki hüviyetine ölmez eserleriyle işaret etmek" amacıyla neşredilmiştir. Bkz. 2'inci Ölüm Yllı Münasebetile Mehmet Âkif (1873-1936), (1938), Ankara: Yüksek Ziraat Enstitüsü Basımevi, 32 s.; 3 'üncü Ölüm Yılı Münasebetile Mehmet Âkif (1873-1936), (1939), Ankara: Yüksek Ziraat Enstitüsü Basımevi, $31 \mathrm{~s}$.

8 Tartışmaların seyri, karşılıklı ithamlar ve cevaplar için bkz. Sessiz Yaşadım, Matbuatta Mehmet Âkif (1936-1940), (2011), hzl. İsmail Kara-Fulya İbanoğlu, İstanbul: Zeytinburnu Belediyesi Yayınları, s. 23-25; 345-645.

9 Maarif Vekâleti'nin kararı için bkz. "Mehmet Âkif’in Mezarını Ziyaret” (28 İlkkânun1940), Tan gazetesi, s. 2.

10 “Mehmet Âkif İhtifali”, (27 İlkkânun 1940), Tan gazetesi, s. 2. 
mayı bir ritüel pratiği olarak her sene icra etmişlerdir bu dönemde. ${ }^{11}$ Üniversite Edebiyat Fakültesi talebeleri, sadece şairin hatırasını yâd etmekle kalmayıp Mehmet Âkif'in kabrinin yapılması için aralarında topladıkları paraları Maarif Vekâleti'ne göndermişlerdir. ${ }^{12}$

Mehmet Âkif'ten 3,5 ay sonra vefat edip resmi törenle "milli şair" sıfatıyla Zincirlikuyu Mezarlığı'na defnedilen Abdülhak Hâmid'in gösterişli cenaze ve anma törenlerine karşın Âkif, taşradaki halkevlerinde vefatından birkaç ay sonra çıkarılan özel dosyalarla anılmaya başlanmıştır. Âkif'in şahsiyetinin, hayatının ve eserlerinin konuşulduğu ihtifaller düzenleyen Merzifon Halkevi'nin aylık kültür dergisi Taşan, 1 Şubat 1937 tarihli Âkif özel sayısıyla -tespit edebildiğimiz kadarıyla- şairin ihtifallerini sivil kurumlar bazında ilk organize eden kurumlardan biridir. ${ }^{13}$ Mehmet Âkif'in hayatı ve şahsiyeti etrafinda özel bir sayı neşreden dergi, vefatından hemen sonra bir "Âkif Gecesi” de düzenlemiştir. Dergide şair "İslamcı, Türkçü, Cemiyetçi” şeklinde üç sıfatıyla tahlil edilmiştir. Bunun haricinde dergi yazılarında Âkif, "Türk edebiyatının en velût ve heyecanlı şairi, iyi kalpli adam, yurdunu çok seven bir vatansever” nitelendirmeleriyle anılmıştır. Dosyada ayrıca Âkif muarızlarına cevap mahiyetinde cümleler dikkat çekmektedir. Küçük çaplı yerel bir teşebbüs olmasına rağmen Taşan dergisi Abdülhak Hâmid (say1 13-37, 1 Haziran 1937) ve Fikret ( say1 16-40, 1 Eylül 1937) için de birer ihtifal özel sayısı neşretmiştir. ${ }^{14}$

Taşra Halkevleri'ndeki bu ilgiye rağmen İstanbul ve Ankara gibi merkezlerdeki halkevlerinde Âkif anmalarına daha geç rastlanmaktadır. Âkif ancak

11 “Mehmed Âkif İhtifali”, (29 Kânunuevvel 1940), Akşam gazetesi, s. 5.

12 Gençlik tarafından toplanıp Maarif'e gönderilen ve para tören için bkz. "Üniversiteliler Yarın Şair Âkif'in Hatırasını Taziz Edecekler", (27 Birincikânun 1940), Son Posta gazetesi, s. 4.

13 Taşradaki Halkevlerinin birçoğu Mehmet Âkif'in vefatından hemen sonra şairin ölümü karşısında duyulan teessür ve duyguları ifade edecek yazılar neşretmişlerdir. Balıkesir Halkevi aylık dergisi Kaynak da bunlardan biridir. Ekrem Çavuldur, "Âkif!" başlıklı yazısında üzüntüsünü dile getirirken, Mehmed Yaşar da "vatanperver ve dinsever" sıfatlarıyla nitelendirdiği Âkif'i o gün "20 milyonu bulan, yarın 100 milyonları aşacak olan Türklerin millî destanını, ebedî marşını yazan İstiklâl şairi” olarak nitelendirmiştir. Mehmed Yaşar'ın, sırf milleti yaşayıp, milleti için yazan ve nihayet çok sevdiği Peygamberi Muhammed gibi 63 yaşında ölen Âkif'in gelecek asırlara kalacak bir kudrete sahip olduğuna işaret eden cümleleri ise şöyledir:

"Hayır, o ölmedi... Ölemez... Ölmeyecek... Gençlik ve Türklük onun muazzez adını nesilden nesile, kıyamete dek nakledecek... Onun yarattı̆̆ marş, İstiklâl Savaşı'nın destanı olarak daima terennüm edilecek”. Bkz. Ekrem Çavuldur, “Âkif”; Mehmed Yaşar, "Yaşıyacak Ölü”, (19 Ocak 1937), Kaynak, sayı 48, , s. 394-395.

14 Bkz. Ahmet Yılmaz, "Büyük Şair Mehmet Âkif’in Ölümü Karşısında”, (1 Şubat 1937), Taşan, Sayı 9-33, s. 1-2, 12. 
ölümünün 6. yıldönümünde İstanbul'daki Halkevlerinde anılmaya başlanacaktır. 17 Aralık 1942 Pazar günü saat 15.30'da Üsküdar Halkevi'nde, bir gün sonra da saat 20.00 'da Eminönü Halkevi'nde üniversite gençliği tarafindan düzenlenen Âkif ihtifalleri, şairin devlet nezdinde yarı resmi kabulünün ilk adımlarıdır. Bu yıllarda Mehmet Âkif’i yalnız bir “din şairi” kabul etmenin doğru olmadı̆̆g, gazetelerin ilk sayfalarında dillendirilmeye de başlanmıştır. ${ }^{15}$

Eminönü Halkevi'nde yapılan Âkif ihtifali sonrası, ilerleyen yıllarda Ankara, Ceyhan ve Tekirdağ'daki halkevlerinde de Âkif anmaları düzenlenmiştir. Bu törenlerde Âkif'e layık görülen sıfat, "İstiklal şairi”dir. "Çanakkale'deki Türk hamasetini ölmez bir şiir abidesi halinde terennüm eden ve kalpleri coşturan İstiklal Marşı'nı yazan şair” sıfatıyla Âkif, saygı ile hatırlanmaya başlanmıştır. Anadolu halkevlerindeki ihtifallerde şairin hayatı, bariz karakterleri, eserlerinin kıymeti nutukların esas meselesi olurken, şiirlerinin okunmasıyla da şairin hatırası yaşatılmıştır. ${ }^{16} \mathrm{Bu}$ tarihten sonra halkevlerinde yapılan Âkif ihtifalleri için gazetelerden ilan verildiği de görülür. ${ }^{17}$

İstanbul'daki ihtifal merkezleri genellikle Üsküdar ve Eminönü Halkevleri'dir. Âkif ihtifallerine avukatından öğretmenine, profesöründen öğrencisine varıncaya kadar her meslekten insan grubu katılım ve ilgi göstermiştir. Talebeler anma programlarında ya şiir okuyarak veyahut dinleyici sıfatıyla hazır bulunmuşlardır. Gençlerin şairin kabrini ziyaret ederek lahdine çelenk koyma seremonileri de gazetelerde göze çarpmaktadır. Genel olarak bu tarihlerde ihtifallerin sürükleyici unsuru üniversite öğrencileridir. ${ }^{18}$ Talebelerin katılımıyla Mehmet Âkif'in hatırasının canlandırıldığı yerlerden biri de Fatih Halkevi' dir. ${ }^{19}$ Halkevlerindeki ihtifallerde hatipler, genellikle Âkif' in hayatta olan yakın dostlarıdır. Üsküdar Halkevi’nde şairin damadı Ömer Rıza

15 “Büyük Vatan Şairi Âkif’in Ölüm Yıldönümü”, “Eminönü Halkevi’nde İhtifal”, (27 İlkkânun 1942 ), Tasvir-i Efkâr gazetesi, s. 1, 3 .

1627 Aralık 1942 günü Bursa Halkevi'nde yapılan ihtifal için bkz. "Mehmet Âkif Gecesi” (1942), Uludağ-Bursa Halkevi dergisi, S. 53-54, İkinciteşrin-Birincikânun, s. 49.

17 Âkif' in damadı Ömer Rıza'nın Üsküdar Halkevi'nde vereceği “Mehmed Âkif ve Şahsiyeti” konulu konferansın ilanı için bkz. "Arkadaşımız Ömer Rıza Doğrul'un Konferansı" (27 Birincikânun 1942 ), Cumhuriyet gazetesi, s. 2.

18 “Şair Mehmed Âkif İçin Dün Üsküdar'da Bir Toplantı Yapıldı”, (28 Birincikânun 1942), Son Posta gazetesi, s. 1.

19 “Mehmed Âkif İhtifali”, (28 Kânunuevvel 1942), Akşam gazetesi, s. 2. 
Doğrul, Âkif'in hayatı, şahsiyeti, ahlakı hakkında verdiği konferanslarla dikkat çekerken ${ }^{20}$, Midhat Cemal Kuntay da hatıralarıyla şairi toplumsal bellekte diri tutan hatiplerin başında gelmektedir.

Maarifçe törenleri kısıtlayan genelgeye rağmen Âkif ihtifallerindeki bu kalabalık, devletin de dikkatinden kaçmamıştır. İhtifalde profesörler, Âkif'in dostları ve yüzlerce gencin haricinde Parti Reisi Suad Hayri Ürgüplü’nün bulunması, siyasi cenahın anma programında gözlemci veya katılımcı sıfatıyla bir şekilde bulunmaya kayıtsız kalamadığını göstermektedir. Edebiyat Fakültesi gençlerinin arzusu üzerine Halkevi idare heyetinden Nusret Safa Coşkun da kısa ve veciz konuşmalarıyla ihtifallerde öne çıkan isimlerdendir. ${ }^{21}$

Âkif anmalarının Fikret'e karşı kasıtlı olarak abartıldığını düşünen ve bu ihtifallere itiraz eden yazarlar da Cumhuriyet döneminde görülür. Zahir Güvemli bunlardan biridir. Güvemli’ye göre "eğer yalnız heyecan şiirse, Âkif alaturka bir şairdir.” Güvemli’nin itiraz ettiği başka noktalar da vardır: İstiklal Marşı şairi Âkif, lüzumundan fazla anıldığı, mütemadiyen Fikret'le kıyas edilmek suretiyle bir türlü inanışın bayrağı yapılmak istendiği için sürekli ihtifaller düzenlenmektedir: "Haşim anılmaz, fakat Âkif anılır. Midhat Efendi bu kadar yılda bir hatıra gelir, fakat Âkif her vesile ile zikredilir." ${ }_{22}^{2}$ Bunu yapan da "Âkifçiler" diye anılmış bir kısım kalem sahipleridir. Yoksa, ne kadar değerli olursa olsun bir adamı -Atatürk müstesna- elbette her yıl anmak doğru bir şey değildir. Güvemli'ye göre eğer bir şahsiyet ciddi ve yaygın bir değer taşıyorsa, değil her yıl, her an, eseriyle, eseri hakkındaki tahlillerle, nihayet dillerde dolaşan mısralarıyla kendini hissettirir. Âkif'ten sekiz yıl içinde eser olarak yaşayan tek şey ise yalnız İstiklal Marşı' dır. ${ }^{23}$ Bir Fikret hayranı olan Güvemli'nin tespitlerinden Âkif' in gereğinden fazla anıldığı sonucu çıkmaktadır.

Güvemli'nin aksine Yüksek Muallim Mektebi ve Üniversite'de Âkif'in vefatının ikinci sene-i devriyesi münasebetiyle 1938 Kânunuevveli'nin 28'nci

20 “Şair Mehmed Âkif İçin Dün Üsküdar'da Bir Toplantı Yapıldı”, (28 Birincikânun 1942), Son Posta gazetesi, s. 1.

21 "Eminönü Halkevi’nde Dün Gece Yapılan Mehmed Âkif İhtifali”, (29 Birincikânun 1942 ), Son Posta gazetesi, s. 1, 3.

22 [Zahir] Güvemli, (30 Birincikânunun 1944), "Mehmet Âkif”, Vakit gazetesi, s. 3.

23 [Zahir] Güvemli, a.g.m., s. 3. 
Çarşamba akşamı yapılan ihtifal kapsamında şairin dostlarından Tâhirü'lMevlevî (Olgun), "Yazı İşleri Direktörü" olduğu Bilgi Yurdu mecmuasında “Âkif’i Nasıl Tanıdım, Nasıl Görüştüm ve Nasıl Gördüm!” başlıklı bir yazı neşretmiş ve ihtifaller dolayısıyla Âkif'in kültürel bellekte hatırlanma gerekçelerini şöyle sıralamıştır:

1. Namık Kemal gibi şiiri düşüncelerinin ve duygularının tebliğine vasıta kılması ve ölümüne kadar kalbinin "din ve vatan aşkı" ile çarpması,

2. Pürüzsüz bir ahenk, temiz ve berrak bir Türkçe ile millî manzaralarımızı, mahallî renklerimizi gözler önüne sermesi ve bütün dikkati, titizliği ile güzel Türkçemizin üzerine titremesi,

3. Arapça ve Farsçaya gayet hâkim olduğu halde arı ve duru Türkçeyi kullanmas1,

4. Asıl muhavere lisanını pek tabii bir surette nazma tatbik etmesi,

5. Mütefekkir bir kafa ile hassas bir kalbin düşünüp duyduklarını sade bir üslup ile ve coşkun bir eda ile tebliği,

6. Hiçbir vakit tasannua (yapmacık) düşürmediği sanatını, sanatkâr görünmek için değil, memlekete ve millete faydalı olmak üzere kullanması,

7. Vatanın parçalanması felaketine karşı hiçbir şairin duyamadığı ve duyuramadığı bir teessürle ağlaması, İstiklal Marşı ile yurdun bağımsızlık saadetini de taklit edilemeyen bir beyan ile alkışlaması.

(Olgun 1929: 569; Fergan 2009: 418-419)

1940'l yılların sonunda Türkiye Milli Talebe Federasyonu'nun ön ayak olduğu Mehmet Âkif ihtifalleri, Tek Parti döneminde nispeten resmi ilgiye mahzar olarak düzenlenmiştir. Artık sivil dernekler ve gençliğin yanında vali (Prof. Dr. Fahreddin Kerim Gökyay), belediye reisi, C.H.P. Bölge müfettişi (Prof. Dr. Sadi Irmak), İstanbul Üniversitesi Talebe Birliği, profesörler ve kalabalık bir kitle de törenlerde hazır bulunmuştur. Şairin yakın dostlarından Midhat Cemal Kuntay, damadı Ömer Rıza Doğrul bu dönemde de ihtifallerin 
önemli hatipleridir. Âkif'in hayat felsefesi, dinî, ahlaki, ictimai tespitlerinden bahisle Safahât'tan seçilmiş bazı şiirlerin okunması, anma merasimlerinde bir gelenek halinde sürdürülen pratiklerdir. Ahmet Ayata, Fethi Gemuhluğolu bu dönemde şiir okuyan genç talebelerdendir. Halkevindeki bu törenler İstanbul Radyosu tarafından yayınlanarak şairin geniş halk kitlelerine ulaşmasının önü açılmıştır. Ayrıca bu tarihte artık birçok halkevinin kapısı Mehmet Âkif için aralanmıştır. $^{24}$

Mehmet Âkif ihtifallerinde 1960'l1 y1llara kadar İstanbul İmam Hatip Lisesi, Milliyetçiler Derneği, Parti Gençlik Kolları, Ankara ve İzmir Türk Ocağ1 Şubeleri, MTTB, Yüksek İslam Enstitüsü, İstanbul Eminönü Öğrenci Lokali, İstanbul Üniversitesi Edebiyat Fakültesi, Edebiyat Fakültesi Mezunları ve Talebe Cemiyetleri dikkat çeken öncü kurumlardır. ${ }^{25}$ Mahir İz, Hikmet Demirçelik, Tarih Profesörü Tayyib Gökbilgin'in yanında, Tuğgeneral Faruk Güventürk de ihtifallerdeki hatip kürsüsünde Âkif'i anlatanlardandır. Şairin talebesi Mahir İz, ölümünün 25. yılında Eminönü Talebe Lokali’nde yaptığı anma konuşmasında "Her geçen yıl onun fikir, sanat ve milli ruh bakımından ne kadar yüksek bir şahsiyet olduğunu daha canlı bir surette belirtmekte ve milletinin kalbinde yaktığı nurlu muhabbet ateşi her yıl daha kuvvetini, şa'şasını arttırmaktadır." tespitiyle kolektif bellekte Âkif' e olan ilgiye bir çerçeve çizmiştir. ${ }^{26}$

Vefatının 40. yıldönümü Mehmet Âkif'in devletin resmi kurumları tarafından sahiplenildiği ilk merhale sayılabilir. Zira bu tarihten sonraki ihtifaller, devletin müdahalesiyle daha planlı ve profesyonel bir çerçevede icra edilirken, içerik bakımından da akademik ve ilmi bir zenginlik kazanmıştır. Sivil teşebbüslerin inisiyatifinde çoğu zaman spontane gelişen organizasyonların yerini, önceden planlanmış ve devletin birçok kurumunun iştirakiyle düzenli bir görünüm arz eden ihtifaller almıştır. Kültür Bakanlı̆̆ı Türk Büyüklerini

24 "Gençlik Mehmet Âkif'i Andı" (28 Aralık 1949), Vakit gazetesi, s. 1.

25 “Millet Şairi Mehmet Akif” (23 Ocak 1962), Sebîlürreşâd, cilt XIV, S. 331, s. 90.

26 Mahir İz, Hikmet Demirçelik, Tarih Profesörü Tayyib Gökbilgin'in yanında, Tuğgeneral Faruk Güventürk'ün konuşmaları için bkz. ““'Millet Şairi Mehmet Akif” (1962), Sebîlürreşâd, cilt XIV, S. 331, 23 Ocak, s. 90-96. 
Anma Serisi'nin 2. kitab1, ölümünün 40. sene-i devriyesinde Mehmet Âkif’e adanırken ihtifal içeriği son derece profesyonel bir görünümdedir. Dönemin Kültür Bakanı Rıfkı Danışman'ın katıldığı ihtifalde Prof. Dr. Mehmet Kaplan, A. Şevket Bohça, Ahmet Yüzendağ, Mehmet Çınarlı gibi isimler ihtifal hatibi kimliğiyle öne çıkarken, Ahmet Hatipoğlu yönetimindeki TRT Korosu da musiki sunumuyla, Haluk Kurdoğlu gibi profesyonel sanatkârlar da şiirleriyle ihtifalin düzeyini amatörden profesyonele taşımıştır. Kültür Bakanlığı'nın o tarihte ihtifallere dair bir kültür politikası geliştirmek istediği Bakan Rıfkı Danışman'ın "Bakanlığımızda Türk edebiyat, sanat, tarih ve sosyal hayatına fikirleri ve eserleri ile değerli hizmetlerde bulunmuş olan şahsiyetlerin çeşitli vesilelerle anılması ve tanıtılması çalışmaları yapılmaktadır." cümlesinden anlaşılmaktadır. $^{27}$

Mehmet Âkif 40. ölüm yıldönümünde Kültür Bakanlığı'nın öncülügünde 29 Aralık 1976 Çarşamba gecesi Cumhurbaşkanlığı Senfoni Orkestrası salonunda anılmıştır. Bu tarih, Âkif ihtifallerinde ayrıca bir milattır. Zira 27 Aralık Pazartesi gecesi televizyonda Mehmet Âkif'i Anma Programı düzenlenmiştir ki şairin İstiklal Marşı haricinde devlet medyasında yankı bulduğu önemli bir tarihin başlangıcıdır. Aynı yıl Hacettepe Üniversitesi tarafından Âkif Semineri 27-28 Aralık günleri yapılmış, seminere İstanbul Üniversitesi, Erzurum Üniversitesi ve Ankara Üniversitelerinden konuyla ilgili bilim adamları katılmışlardır. Âkif'in devlet ve üniversiteler araçlığıyla organize bir biçimde anıldığı en önemli tören silsilesi bu dönemde başlar denilebilir. ${ }^{28}$

1978 yılında Ankara'da 14 yazar, şair, romanc1, öykücü ve yayıncının bir araya gelerek Türkiye Yazarlar Birliği’ni kurmasının ardından Mehmet Âkif ihtifalleri tabana hızla yayılarak şaire dair toplumsal farkındalık çalışmaları artmıştır. Âkif'in bir müddet ikamet ettiği ve İstiklal Marşımızı ve

27 Mehmet Âkif'in Anma Günü programı için bkz. Ölümünün 40. Yllında Mehmet Âkif Ersoy (1873-1936), (1976) hzl. Mustafa Özen-A. Şevket Bohça, Ankara: Kültür Bakanlığı Yayınları, 28 s.

28 Televizyondaki anma programında Yavuz Bülent Bakiler Mehmet Âkif'in Hayatı ve Kişiliği, Mehmet Çınarlı Âkif'in Şiir Dünyası, Fevziye Abdullah Tansel ise Âkif'in Fikirleri üzerinde konuşmuşlardır. Programın sonunda Âkif'in kızı Feride Akçor'la yapılan bir röportaj yayınlanmıştır. Bkz. "Mehmet Âkif Anıldı" (1977), Hisar dergisi, S. 157, Ocak, s. 2. 
Bülbül'ü kaleme alındığı Samanpazarı'ndaki Tâceddin Dergâhı, Hacettepe Üniversitesi tarafından müze haline getirilmiş ve ardından burada 20-27 Aralık tarihleri arasında düzenli olarak merasimler yapılmaya başlanmıştır. ${ }^{29}$

Milli şairimiz Mehmet Âkif Ersoy için ikinci ve en önemli kültürel seferberlik, ölümünün 50. yıldönümünde "iade-i itibar” sayılabilecek bir şekilde devletin bütün resmi organlarının katılımıyla gerçekleştirilmiştir. 1987 yıl1, ilk defa şaire adanan bir sene olmuş, ihtifaller haricinde Mehmet Âkif Yllı'nda şairin şahsiyeti ve eserleri üzerine kültürel bir seferberlik ilan edilmiştir. Dönemin Kültür ve Turizm Bakanı Mükerrem Taşçığlu'nun Mehmet Âkif Ersoy’un ölümünün 50. yıldönümü dolayısıyla 16.7.1986 tarihinde yaptığı basın toplantısında sarf ettiği şu sözler, Âkif'in 1986 yılına kadar devlet tarafından nispi olarak yok sayıldığının itirafı niteliğindedir:

“Bugüne kadar istiklal Marşı Şairimiz Mehmet Âkif Ersoy'un kendisine layık
bir şekilde anılmış olduğunu söylemek güçtür. 50. yıldönümünde hiç değilse
bu kusurlarımızı bir nebze tamir edebilmek ve ona karşı saygı borcumuzu ifa-
de edebilmek için yapmayı düşündüğümüz faaliyetleri arz etmek istiyorum...”
(Taşçığlu 1986: 3 ).

1986 y1lında Mehmet Âkif’in anılmasıyla ilgili faaliyetler aylar öncesinden başlamış, TBMM Başkanı Necmettin Karaduman, Başbakan Turgut Özal, Genel Kurmay Başkanı Orgeneral Necdet Ürug, Milli Eğitim Gençlik ve Spor Bakanı Metin Emiroğlu, Kültür ve Turizm Bakanı Mükerrem Taşç1oğlu, Yüksek Öğretim Kurulu Başkanı Prof.Dr. İhsan Doğramacı'dan meydana gelen bir "Şeref Kurulu" oluşturulmuştur. Anma töreni ve faaliyetler serisi için 200 milyon ile 2 milyar arasında tasarlanan bir mali portre hesaplanmış ve bu amaçla Çanakkale'deki Şehitler Abidesi projesinde olduğu gibi bağışlar için Türkiye Vakıflar Bankası Yenişehir Şubesi'nde hesap açılmıştır. ${ }^{30}$

Âkif-Fikret kıyaslamasıyla daha çok beliren lehte ve aleyhte yazılar,

29 Ölüm yıldönümünde Yazarlar Birliği’nin ilk organize Âkif anmalarına dair örnek olarak bkz. "Mehmet Âkif Anıldı" (1979), Hisar dergisi, S. 256, Ocak-Şubat, s. 33.

30 Mükerrem Taşçığlu (1986), "Sunuş”, Milli Şair Mehmet Âkif Ersoy’u Ölümünün 50. Yıldönümünde Anma Faaliyetleri Kitapçı̆̆ı, Ankara: Kültür ve Turizm Bak. Yayınları, s. 4. 
İstiklal Marşı tartışmaları da ${ }^{31}$ 1986-87 yılının edebiyat gündeminde yer alan konulardandır. Prof. Dr. Şükrü Elçin'in imtiyaz sahibi olduğu Türk Kültürü̈², Türk Edebiyatt ${ }^{33}$, Milli Kültür ${ }^{34}$ vb. dergiler, özel sayılarla vefatının ellinci yılında Mehmet Âkif'i çeşitli yönleriyle ele almışlardır. Türk Edebiyatı Vakfı, öğretim üyeleri, öğretmenler, üniversite ve lise öğrencilerini kapsayan ödüllü bir Mehmed Âkif Şiir Tahlili ve Resim Yarışması düzenlemiştir. ${ }^{35}$ Ölümünün ellinci yılında edebiyat muhitlerindeki genel kanaat, "İstiklâl Marşımız"1 yazan, milletimizin ve devletimizin buhran devirlerinde millî dert ve davalarım1Z1 ve İslâm âleminin meselelerini hayatının temel konusu olarak işleyen iman ve ahlâk timsali, mücadeleci fikir adamı Mehmet Âkif Ersoy’un “ebediyyen millî şâirimiz olarak anılmaya layık” olduğudur (Bilgiç 1986, 21).

1986’nın ilk günlerinde şairi “rahmet ve minnetle anma için” ihtifal maksadıyla bir araya gelen Aydınlar Ocağı ve Türk Edebiyatı Vakfı, bu dönemde dikkat çeken iki teşekküldür. "Türk aydını olmanın şuuru ve mesuliyet idrakiyle” kurulan bu kurumlar, “Âkif'i tanımak, onu sevmek, ona benzemeye çalışarak onu anmak her Türk'ün borcu ve vazifesidir." sloganıyla anma toplantıları düzenlemeyi misyon olarak kabul etmişlerdir. ${ }^{36}$

Türkiye Yazarlar Birliği yanında Marmara Üniversitesi İlâhiyat Fakültesi Vakfı bünyesinde kurulan Mehmet Âkif Araştırmaları Merkezi de, şairin vefatının ellinci yılında şairi kolektif bellekte yaşatma ve neşriyatla edebî mi-

\footnotetext{
31 Bazı çevrelerce periyodik aralıklarla nükseden İstiklal Marşı tartışmalarını "íçinde bulunduğumuz 1986 senesi,

Âkif'in 50. ölüm yıldönümüne rastliyor. Bu münasebetle, millî şairimiz, çeşitli kuruluşlar tarafindan tertiplenen toplantılarla ve yapılan neșriyatla bir kere daha yâd ediliyor. Buna karșılık, bazı çevreler İstiklal Marșı'nı değiștirilmesi için elverişli ortam hazırlayıp kampanya açmağa çalışıyorlar." özetleyen Altan Deliorman 1986 yılındaki cevabına örnek olarak bkz. Altan Deliorman, "İstiklal Marşı Değiştirilebilir mi?”, (13 Kasım 1986), Tercüman gazetesi, 8.

3211 araştırmacının Âkif'e dair akademik nitelikteki makaleleri için bkz. "Mehmed Âkif Ersoy Sayısı", (1986), Türk Kültürü, S. 284, Aralık, s. 729-832.

33 Yaklaşık 30 araştırmacının yazı ve incelemelerini ihtiva den özel dosya için bkz."Mehmed Âkif Anıt Sayısı" (1986), Türk Edebiyatı, S.158, Aralık 1986, s. 3-95.

34 Milli Kültür'ün Mehmet Âkif Ersoy özel sayısı için bkz. Milli Kültür (1986), S. 55, Aralık, s. 1-96.

35 Yarışmaya son katıma tarihi 1 Şubat 1987’dir. Derece alan eserlere ödüller istiklâl Marşı’ nın kabul yıldönümü olan 12 Mart 1987 tarihinde verilmiştir. Bkz. "Mehmed Âkif Şiir Tahlili ve Resim Yarışması" (1986), Türk Edebiyatı, S.158, Aralık, s. 94 .

36 Genel Başkanlığını Prof. Dr. Süleyman Yalçın'ın yaptığı Aydınlar Ocağı Yayınları'ndan çıkan kitapta Yard. Doç. Dr. Kâzım Yetiş, Ahmed Kabaklı, A. Aydın Bolak, Yard. Doç. Dr. Necat Birinci, Prof. Dr. Muharrem Ergin birer makaleyle Mehmed Âkif'in şahsiyete 1şık tutmaya çalışmıştır. Bkz. Mehmed Âkif'i Anlattyorlar (1986), İstanbul: Doğuş Matbaası, s. 13.
} 
rasını geleceğe taşıma gayretiyle harekete geçen kurumlardandır. Merkezin Müdürlüğü yapan M. Ertuğrul Düzdağ, 1986 yılında kurumun amacını şöyle açıklamıştır:

“Merkez'imiz Mehmed Âkif Ersoy’u tanıtmak ve bütün eserlerini yayınlayarak millî kültürümüze faydalı olmak gâyesiyle kurulmuştur ve Mehmed Âkif'i seven aziz milletimizin bütün ferdlerinden yakın alâka ve yardım göreceğinden emin bulunmaktadır."

Kültür ve Turizm Bakanlığı'nın proje kapsamında Milli Şairimizin hayatını, düşünce ve sanatını, Milli Mücadele ve Milli Edebiyatımızdaki yerini inceleyen "Mehmet Âkif Ersoy" kitabı, yine şairin ölümüne kadar yazmış olduğu bütün yazılar taranıp derlenerek ve eski harflerle yazdığı halde yeni harflere geçirilmemiş, tasnif edilerek kitap halinde basılmamış yazıları (Mehmet Âkif Ersoy'un Yazılarl), Mehmet Âkif Ersoy Bibliyografyası, TBMM "İstiklal Marşı" ile ilgili zabıtlar kitab1 1986'da kamuoyuna ilan edilen neşriyat faaliyetlerindendir. Mehmet Âkif' in 1986-1987 y1lındaki anma merasimlerine hemen hemen bütün devlet bakanlıkları yanında YÖK, Atatürk Kültür Dil ve Tarih Yüksek Kurumu Başkanlığı, TRT Genel Müdürlüğü, Vakıflar Genel Müdürlüğü, Basın Yayın ve Enformasyon Genel Müdürlüğü, PTT İşletmesi Genel Müdürlüğü, Türkiye Bankalar Birliği, Mehmet Âkif Ersoy Fikir ve San'at Vakfı, Türkiye Diyanet Vakfı, Tarihi Araştırmalar ve Dokümantasyon Merkezleri Kurma ve Geliştirme Vakfi, Türk Kültürüne Hizmet Vakfi, Kütüphaneler ve Yayımlar Genel Müdürlüğü, Güzel Sanatlar Genel Müdürlüğü, Milli Kütüphane Başkanlığı da kendi sahasına taalluk eden faaliyetlerle iştirak etmişlerdir. $^{38}$

1986 y1lından itibaren Mehmet Âkif ismi zaman zaman siyasi tartışmalara malzeme yapılsa da ihtifaller üniversitelerin, edebî teşekküllerin, gönüllü sivil toplum kuruluşlarının, vakıf ve derneklerin gayretleriyle 21. yüzyıla 
ulaşıncaya kadar aksamadan devam edegelmiştir. Hayatında Âkif'e esirgenen vefa, ölümünden sonraki törenlerle telafi edilmiştir.

2000'li yıllardan sonra Mehmet Âkif için kanuni düzenlemeler yapılarak şairin kamuoyundaki itibarını, eserlerini korumaya yönelik birtakım girişimler de hayata geçirilmiştir. 4 Mayıs 2007 tarihli 5649 sayılı kanunla her yı1, İstiklal Marşı'nın kabul edildiği gün olan 12 Mart, “Mehmet Âkif Ersoy'u Anma Günü” olarak tescil edilmiştir. Kanunla, bütün kamu kurum ve kuruluşlarının öncülüğünde, halkın ve sivil kurumların iştirakiyle anma törenleri düzenlenmesi öngörülmüştür. ${ }^{39} 2010$ y1lında ise 1126 sayılı kanunla İstiklal Marşı'nın 5846 sayılı Fikir ve Sanat Eserleri Kanunu kapsamında korunan mali haklara konu edilemeyeceği hüküm altına alınmıştır. Kültür ve Turizm Bakanlığının 3/12/2010 tarihli ve 244972 say1lı yazısı üzerine Bakanlar Kurulu'nca 6/12/2010 tarihinde kararlaştırılan bu kanuna göre hiçbir gerçek ya da tüzel kişi, kurum, kuruluş veya birlik İstiklal Marşı'nın çoğaltılması, yayılması, temsili, ses veya görüntü karş1lığında bedel talep edemeyecektir. ${ }^{40}$

Devlet tarafından bir yılın Mehmet Âkif'e tahsisi, 1987 y1lından sonra 2011 yılında da gerçekleşmiştir. Bu yılın milli şairimiz "Mehmet Âkif Ersoy Y1lı" ilan edilmesinin ardından vefatının 75. yıldönümünde tüm ülkede çeşitli programlarla anılmaya başlanan Mehmet Âkif adına "Vefa Geceleri” düzenlenmiştir. 12-13 Mart 2011 tarihlerindeki Uluslararası Mehmet Âkif Ersoy Sempozyumu'nda 35 araştırmacı ve akademisyen, İstiklal Marşı şairini “dönemi, düşüncesi, şiiri-dili, Safahât adlı eseri, tahayyülü/yansımaları” yönüyle ele almıştır. Yaşayan kültürde Mehmet Âkif imgesi sorgulanırken, şairin üç açıdan ilgi odağı haline geldiği saptanmıştır: Şairliği, İslamcılığı ve Karakteri. ${ }^{41} 2011$ yılında Mehmet Âkif hakkında özel sayılar neşreden dergiler de şairin aktüel zamana mesaj ve tesirlerini farklı başlıklar altında değerlendir-

39 Yönetmeliğin çıkarılmasında İçişleri, Milli Eğitim ile Kültür ve Turizm bakanlıklarının müşterekiyeti ön görülmüştür. 4 Mayıs 2007 tarihinde kabul edilen kanun için bkz. “İstiklal Marş1'nın Kabul Edildiği Günü ve Mehmet Âkif Ersoy’u Anma Günü Hakkında Kanun”, Resmî Gazete, S. 26518, 10 Mayıs 2007/Kanun no. 5649.

40 Bakanlar Kurulu kararı ve Karanmenin Eki için bkz. Resmî Gazete, S. 27780, 9 Aralık 2010/Kanun no. 1126.

41 Bkz. Doç. Dr. Yılmaz Daşçıŏlu, "Yaşayan Kültürde Mehmet Âkif İmgesi”" (2011), Vefatının 75. Yllında Mehmet Âkif Ersoy-Sempozyum Bildirileri, hzl. Vahdettin Işık, İstanbul: Zeytinburnu Bel. Kültür Yayınları, s. 556. 
meye tabi tutmuştur. ${ }^{42}$ Başbakanlık Osmanlı Arşivi ve Cumhuriyet Arşivi’nde bulunan ve şairin biyografisine katkı sunacak belgeler de bu tarihten itibaren yoğun bir şekilde neşredilmeye başlanmıştır (Anar 2011: 179-203).

Son olarak Mehmet Âkif Ersoy’un vefatının 84. yıldönümünün idrak edileceği hafta 30 Aralık 2020 tarihli ve 31350 sayılı Resmî Gazete'de yayımlanan genelge ile 2021, “İstiklal Marşı Yılı” olarak ilan edilmiştir. Genelge, 2021 y1lı boyunca bütün kamu kurum ve kuruluşları tarafından İstiklal Marşı’nın anlamını ve Kurtuluş Savaşı'nın önemini anlatmak amacıyla halkımızın ve sivil toplum kuruluşlarının katılımıyla İstiklal Marşı’nın kabulü ve Mehmet Âkif Ersoy’la ilgili anma etkinlikleri düzenlemeyi öngörmüştür. 43 İstiklal Marşı'nın kabulünün 100. yılı (12 Mart 2021), böylece Mehmet Âkif' in hatırlanmasında önemli bir fırsat zemini hazırlamıştır. 12 Mart öncesi ve sonrasında, yıl boyunca şairin hayatı, eserleri ve sanatı, İstiklal Marşı etrafinda birçok yayın ve neşriyat yapılmıştır. ${ }^{44} 100$. yıl kapsamında ayrıca birçok üniversite tarafından sempozyum, panel ve çalıştay düzenlenmiş, Mehmet Âkif' in Mısır dönüşü bir müddet ikamet ettiği Mısır Apartmanı'ndaki dairesi "Mehmet Âkif Ersoy Hatıra Evi”" olarak devletin resmi makamlarının katıl1miyla Kültür ve Turizm Bakanlığ tarafından 12 Mart 2021 tarihinde ziyarete açılmıştır. ${ }^{45}$ İstiklal Marşı'nın kabulünün 100. y1lı için başta İstanbul olmak üzere birçok ilde sergiler açılmış ve söyleşiler gerçekleştirilmiştir. Böylece yeryüzünde kendisini hatırlatmaya değer kalıcı izler bırakamadığını düşünen şair, edebî hafizada adeta yeniden dirilmiş; eserleriyle, şiirleriyle kamuoyu-

42 Mehmet Âkif Özel sayısı neşreden Diyanet İlmi dergisinin kitap basımı için bkz. Vefatının 75. Yılını Anısına Mehmet Âkif Ersoy (2013), Ankara: DİB Yayınları, s. 7-199.

434 Mayıs 2007 tarihli ve 5649 sayılı İstiklal Marşı'nın Kabul Edildiği Günü ve Mehmet Âkif Ersoy’u Anma Günü hakkındaki kanuna eklenen geçici madde için bkz. Resmî Gazete, S. 31350, 30 Aralık 2020, s. 9.

44 Örnek olarak bkz. Türk Dili, (Mart 2021), S. 831, s. 6-125.

Tespit edebildiğimiz kadarıyla 2021 yılında Mehmet Âkif ve eserlerini konu olan 40'a yakın kitap çeşitli belediyeler, kamu kurumları, yayınevleri, dernek ve vakıflar tarafından neşredilmiştir. Bunun yanında birçok dergi ve mecmua da özel sayılarla bu yılda Âkif'e dair yayınları edebiyat tarihimize miras bırakmıştır.

45 Dairenin ilk odası Mehmet Âkif Ersoy Kitaplığı olarak tasarlanmıştır. Şiir odası, belgesel odası ve Mehmet Âkif Ersoy’un hayatına dair kesitlerin yer aldığı dijital sergileme alanları da bulunmaktadır. Ayrıca Mehmet Âkif’e ait fotoğraflar, gözlügü, saati, kitapları, eserlerinin orijinal basımları, vefatının ardından adına basılan pulu, zarfı ve paraları sergilenen eşyalar arasından yer almaktadır. Hatıra Evi, Âkif' in anılarını yaşatan bir merkeze dönüşürken, ziyaretçilerine Âkif'i daha yakından tanıma imkânı sunmaktadır. Bkz. "Mısır Araptmanı'nda Hatıra Evi”, (Nisan 2021), Dergâh, S. 374, s. 2. 
nun gündeminde kültürel dinamikliğini kazanmış, her firsatta kaçındığı şöhreti yaşarken değil ama öldükten sonra toplumun gönlündeki sevgiyle bir daha kazanmıştır.

\section{Sonuç Yerine}

Toplumsal belleğin ve edebî hafızanın işleyişini göstermesi bakımından Mehmet Âkif ihtifalleri ideal bir örnek niteliğindedir. Dinî, milli birçok geleneği içinde barındıran bu anma merasimleri, kendisine özgü birtakım ritüellerin de ortaya çıkmasına imkân tanımıştır. İhtifaller, şairin hayatına, sanatına ve eserlerine dair yeni bakış açılarının ortaya çıkmasına vesile olduğu gibi edebî polemiklerle kültürel hafizanın canlanmasına da hizmet etmiştir. Mehmet Âkif'e dair ilmi ve akademik araştırmaların, etütlerin artmasında bir ritüel pratiği olan bu ihtifallerin rolü büyüktür.

Resmi ilgiden mahrum olarak 28 Aralık 1936'da sessiz bir şekilde Edirnekapı'ya defnedilen Mehmet Âkif'in devletin bütün kurumlarının iştirakiyle anılacağ 1 günler için 40, 50 yılın geçmesi gerekmiştir. O, vefatından itibaren, gençlik ve sivil teşebbüsler sayesinde, İstanbul ve Ankara başta olmak üzere, Anadolu'nun muhtelif şehirlerinde törenlerle anılırken, bir müddet sonra da Halkevlerini fethetmiş ve böylece devletin desteklediği yarı resmi kurumlara, sağlı̆̆ında değil ama öldükten sonra defalarca adım atabilmiştir. Rahmetle anılmayı, ebediyete ulaşmanın ön şartı sayan Âkif'in kaleminden çok yüreğinden dökülen "Sessiz yaşadım, kim beni nerden bilecektir?" endişesinde haksız olduğu, ölümü sonrası kendisine ve eserlerine gösterilen ilgi ve vefa ile her firsatta tekzip edilmiştir. Mehmet Âkif ihtifalleri, vefa duygularının ağırlık kazandığı özel dilimler olmasıyla birlikte şairin gerek özel hayatı (ailesi, tercihleri, Mısır inzivası, Kuran tercümesi, oğlunun trajedisi vb.) gerekse eserleri üzerinden sorgulandığı, tartışıldığ 1 , anketlere konu olduğu ritüel safhalarıdır. Daha çok gençlerin, talebelerin ön ayak olduğu anma toplantılarına zamanla devlet de kayıtsız kalamamış, şaire "iade-i itibar" verecek 
şekilde kanunlar ihdas ederek Mehmet Âkif'in eserlerini (İstiklal Marşı gibi) korumaya almıştır. Doğum ve ölüm yıldönümlerindeki ihtifalleri, bir taraftan şairin kültürel bellekte daha çok anılmasına firsat sunarken, diğer taraftan yarışmaların düzenlenmesine, ithaf şiirlerinin yazılmasına, eserlerinin bestelenmesine hizmet ederek edebî ürünlerin neşrine firsat sunmuştur.

Vefatından elli sene sonra Mehmet Âkif (1986), Prof. Ayhan Songar'ın ifadesiyle, artık “İstanbul'da meydan meydan, mahya mahya, bütün vatanda ise tek gönül, tek yürek, tek ses halinde anılmış, adı günden güne adetâ bayraklaşmışırı." (Songar 1987: 2). Aynı teveccüh, şairin 100. vefat yıldönümüne 15 y1l kala, İstiklal Marşımızın da kabulünün 100. sene-i devriyesinde artarak devam etmektedir. Ne var ki Mehmet Âkif ihtifallerinin sıkça düzenleniyor olmasının bazı olumsuz yönleri de göze çarpmaktadır. Plansız, acele ile, dağınık ve düzensiz bir şekilde düzenlenen bazı anma programları çerçevesinde şaire gösterilen aşırı ilgi, kolektif bellekte Âkif algısını, zaman zaman mitik yönleriyle realist zeminden uzaklaştırarak romantik imgelerle kurgulanmış efsanevi bir karaktere büründürmüştür. Kanaatimizce Mehmet Âkif'in edebî değerini ortaya koyacak, örnek şahsiyetine 1şık tutacak ciddi araştırma ve incelemeler, neşriyatlar doğum ve ölüm yıldönümlerinde kendisine yapılacak en büyük vefa göstergesi olarak edebî hafızada daha çok kıymet kazanacaktır. 


\section{Kaynakça}

2'inci Ölüm Yllı Münasebetile Mehmet Âkif (1873-1936), Ankara: Yüksek Ziraat Enstitüsü Basımevi, 1938.

3'üncü Ölüm Yılı Münasebetile Mehmet Âkif (1873-1936), Ankara: Yüksek Ziraat Enstitüsü Basımevi, 1939.

Assman, Jann (2015), Kültürel Bellek: Eski Yüksek Kültürlerde Yazı, Hatırlama ve Politik Kimlik, çev. Ayşe Tekin İstanbul: Ayrıntı Yayınları.

Ayvazoğlu, Beşir (2007), Kâinatça Tanınmış Türk Şiir Kralı Florinalı Nâzım ve Şaşalı Edebî Hayatı, İstanbul: Kapı Yayınları.

Bir İstiklâl Âşığl Mehmet Âkif (Hayatı, Sanatı, Fikirleri Üzerine Araştırma ve İncelemeler) (2011), ed. [editör] Turgay Anar, İstanbul: Dün Bugün Yarın Yayınları.

Connerton, Paul (1999), Toplumlar Nasıl Anımsar? çev. Alâeddin Şenel, İstanbul: Ayrıntı Yayınları.

Düzdağ, M. Ertuğrul, Büyük Şairin Vefatının Ellinci Yılında: İstiklal Marşı ve Çanakkale Şehidleri Şiirlerinin Açıklaması (1986), İstanbul: Mehmed Âkif Araştırmaları Merkezi Yayınları.

Ersoy, Mehmet Âkif (2001), Safahât, hzl. Prof. Dr. Cemal Kurnaz..., İstanbul: MEB Yayınları.

[Fergan], Eşref Edib (2009), Mehmed Âkif: Hayatı, Eserleri ve Yetmiş Muharririn Yazıları, hzl. Fahrettin Gün, İstanbul: Beyan Yayınları.

Hobsbawm Eric, -Terence Ranger (2006), Geleneğin İcadl, İstanbul: Agora Kitaplı̆̆ı.

Hakan T. Karateke (2017), Padişahım Çok Yaşa: Osmanlı Devleti'nin Son Yüzyılındaki Merasimler, İstanbul: Türkiye İş Bankası Kültür Yayınları.

Kuzucu, Kemalettin (2018), Kahramanı Yaratmak: Itttihadcıların Alemdar Mustafa Paşa'yı Hatırlaması, İstanbul: Timaş Yayınları.

Mehmed Âkif'i Anlatıyorlar (1986), İstanbul: Doğuş Matbaası.

Okay, Prof. Dr. M. Orhan (1989), Mehmed Âkif-Bir Karakter Heykelinin Anatomisi, Ankara: Akçă̆ Yayınları, 1989.

Ölümünün 40. Yllında Mehmet Âkif Ersoy (1873-1936), hzl. Mustafa Özen-A. Şevket Bohça, Ankara: Kültür Bakanlığı Yayınları, 1976.

Mehmet Âkif (1937), Toplayanlar: M. Sencer-N. Salih, İstanbul: Bozkurt Basımevi.

Mehmet Âkif'in Kabri İçin (t.y.), İstanbul: y.y.

Paul Ricoeur (2012), Hafiza-Tarih-Unutuş, çev. M. Emin Özcan, İstanbul: Metis Yayınları.

Sessiz Yaşadım (2011), Matbuatta Mehmet Âkif (1936-1940), hzl. İsmail Kara-Fulya İbanoğlu, 
İstanbul: Zeytinburnu Belediyesi Yayınları.

Şemseddin Sâmi (1317/1899), Kâmûs-ı Türkî, Dersaâdet, İkdam Matbaası.

Tarlan, Dr. Ali Nihat, Mehmet Âkif(1939), İstanbul: Sühulet Basımevi, 1939.

Vefatının 75. Yılında Mehmet Âkif Ersoy-Sempozyum Bildirileri (2011), hzl. Vahdettin Işı, İstanbul: Zeytinburnu Bel. Kültür Yayınları.

Vefatının 75. Yılını Anısına Mehmet Âkif Ersoy (2013), Ankara: DİB Yayınları.

\section{Süreli Yayınlar}

“Arkadaşımız Ömer Rıza Doğrul’un Konferansı” (27 Birincikânun 1942), Cumhuriyet gazetesi, s. 2 .

Bilgiç, Prof. Dr. Emin (1986), “Ölümünün Ellinci Yılında Millî Şâirimize İhtirâm”, Türk Edebiyat, S. 158, Aralık, s. 21-23.

“Büyük Vatan Şairi Âkif’in Ölüm Yıldönümü”, “Eminönü Halkevi’nde İhtifal” (27 İlkkânun 1942), Tasvir-i Efkâr gazetesi, s.1, 3.

Çavuldur, Ekrem, “Âkif”; Mehmed Yaşar, "Yaşıyacak Ölü”, (19 Ocak 1937), Kaynak, sayı 48, , s. 394-395.

Çoruk, Ali Şükrü (2016), “Bir Gelenek İcadı Olarak II. Meşrutiyet Döneminde Gerçekleştirilen İstanbul'un Fethi Törenleri”, FSM İlmî Araştırmalar, S. 7, Bahar, s. 79-98.

Ergun, Celâl (1947), "Eski Galatasaraylıları Tanıyalım 1: İhtifalci Mehmet Ziya Bey”, Galatasaray dergisi, S. 3, Ağustos , s. 22.

Eyice, Prof. Dr. Semavi (2003), "İhtifalci Mehmet Ziya Bey: Hayatı, Mezarı ve Eserleri”, Eyüpsultan Sempozyumu VI-Tebliğler, İstanbul: Eyüp Belediyesi Kültür Yayınları, s. 172-181.

“Gençlik Mehmet Âkif’i Andı” (28 Aralık 1949), Vakit gazetesi, s. 1.

Gezgin, Hakk1 Süha, (29 Birincikânun 1940) “Âkif'in Mezarında”, Vakit gazetesi, s. 3.

Gövsa, İbrahim Alâettin (15 İkincikânun 1939), “Mehmet Âkif’e Dair”, İkdam gazetesi, s. 3.

Güvemli, [Zahir], (30 Birincikânunun 1944), "Mehmet Âkif”, Vakit gazetesi, s. 3.

“Mehmet Âkif Dün Öldü” (28 Birincikânun/Aralık 1936), Akşam gazetesi, s. 10.

“Mehmet Âkif'in Mezarını Ziyaret” (28 İlkkânun 1940), Tan gazetesi, s. 2.

“Mehmed Âkif İhtifali” (29 Kânunuevvel 1940), Akşam gazetesi, s. 5.

“Mehmed Âkif İhtifali” (28 Kânunuevvel 1942), Akşam gazetesi, s. 2.

"Mehmet Âkif Gecesi” (1942), Uludağ-Bursa Halkevi dergisi, S. 53-54, İkinciteşrinBirincikânun, s. 49. 
“Mısır Araptmanı’nda Hatıra Evi” (2021), Dergâh, S. 374, Nisan, s. 2.

Necatigil, Behçet (1975), “Garnitür”, Yeni Dergi, S.125, Şubat, s. 4.

"Mehmet Âkif Anıldı" (1977), Hisar dergisi, S. 157, Ocak, s. 2.

"Mehmet Âkif Anıldı" (1979), Hisar dergisi, S. 256, Ocak-Şubat, s. 33.

Olgun, Tahir (1939), “Âkif’i Nasıl Tanıdım, Nasıl Görüştüm ve Nasıl Gördüm!”, Bilgi Yurdu Mecmuası, S. 6, İkincikânun, s. 569.

“Mehmed Âkif Anıt Sayısı” (Aralık 1986), Türk Edebiyatı, S. 158, s. 3-95.

Resmî Gazete, S. 26518, 10 May1s 2007/Kanun no. 5649.

Resmî Gazete, S. 27780, 9 Aralık 2010/Kanun no. 1126.

Resmî Gazete, S. 31350, 30Aralık 2020, s. 9.

Schudson, Michael (2007), "Kolektif Bellekte Çarpıtma Dinamikleri”, Cogito, S. 50, YKY Bahar, s. 179-199.

Songar, Prof. Ayhan, (4 Ocak 1987), “Âkif’i Anarken”, Tercüman gazetesi, s. 2.

“Şair Mehmed Âkif İçin Dün Üsküdar'da Bir Toplantı Yapıldı” (28 Birincikânun1942), Son Posta gazetesi, s. 1 .

“Üniversiteliler Yarın Şair Âkif'in Hatırasını Taziz Edecekler” (27 Birincikânun 1940), Son Posta gazetesi, s. 4.

Yılmaz, Ahmet (1937), "Büyük Şair Mehmet Âkif’in Ölümü Karşısında”, Taşan, S. 9-33, 1 Şubat, s. 1-2, 12 . 